\title{
Responses to environmental and socio-economic changes in the Karangwangi traditional agroforestry system, South Cianjur, West Java
}

\author{
JOHAN ISKANDAR ${ }^{1}$, BUDIAWATI SUPANGKAT ISKANDAR ${ }^{2}$, RUHYAT PARTASASMITA ${ }^{1, \bullet}$ \\ ${ }^{1}$ Department of Biology, Faculty of Mathematics and Natural Sciences and Postgraduate of Environmental Study (PSMIL \& DIL) and Institute of \\ Ecology (PPSDAL), Padjadjaran University. J1. Raya Bandung-Sumedang Km 21, Jatinangor, Sumedang 45363, West Java, Indonesia. Tel +62-22 \\ 7797712. `email: ruhyat.partasasmita@unpad.ac.id \\ ${ }^{2}$ Department of Anthropology, Faculty of Social and Political Science, Padjadjaran University. Jatinangor, Sumedang 45363, West Java, Indonesia
}

Manuscript received: 15 December 2015. Revision accepted: 15 April 2016.

\begin{abstract}
Iskandar J, Iskandar BS, Partasasmita R. 2016. Responses to environmental and socio-economic changes in the Karangwangi traditional agroforestry system, South Cianjur, West Java. Biodiversitas 17: 332-341. In the past, the swidden agriculture system (huma) was dominant in village frontiers of West Java; including in the Karangwangi Village of Cidaun Sub-district, Cianjur District, West Java Province. Culturally, each Karangwangi household owned a right to cultivate upland rice (huma) by felling mature forest (leuweung). Moreover, the land was planted by upland rice and other annual crops, such as corn, cassava, cucumber, and various beans. After harvesting rice and other annual crops, the land was fallowed and transformed into secondary forest (reuma) through natural succession. Moreover, the mature secondary forest (reuma kolot) could be opened for rice planting again in the following year or fallowed for more than 3-5 years. People will shift to another piece of mature secondary forest for rice planting. Today, because of increasing population, decreasing forests, and increasing market economic penetration, the Karangwangi people have predominantly practiced the swidden farming in the non-forest instead of the forest. The forests had culturally been converted to traditional agroforestry systems, such as mixed-garden (kebon tatangkalan), and homegarden (pekarangan).This paper discusses the process of evolution of the swidden farming and innovatory cultural practice among the Karangwangi community, South Cianjur, West Java, in management of the traditional agroforestry systems which have been dynamically affected by ecological and socio-economic changes. Four parts are presented in this paper. In part one, we account for the Karangwangi people used to practice the swidden farming in the forest when the forest area that was still abundant. In part two, we discuss a focus on process of the evolution of the swidden farming, transformed to the traditional agroforestry systems In part three, we elaborate on some changes of the traditional agroforestry system and responses to environmental changes. In part four, it is summarized and inferred of the paper. Based on this study, it can be inferred that by developing innovatory cultural practice, Karangwangi people of South Cianjur, West Java have tended to success to evolve their swidden farming to new condition of the traditional agroforestry systems in sustainable way, despite population growth, the depletion of the forests, and intensive market economic penetration.
\end{abstract}

Keywords: Karangwangi Village, socio-economic changes, traditional agroforestry system

\section{INTRODUCTION}

Swidden agriculture, shifting cultivation, slash-andburn cultivation or long fallow agriculture system which is called as ladang (Indonesia) or huma (Sundanese) was very popular in the frontier upland West Java and South Banten areas in ancient time (Haan 1912; Kools, 1935;Terra 1953; Geertz 1963; Iskandar 1998; Breeman 2014). Because at that time, the human population was low, forest was abundant, land was the cheap resource, labor was the expensive resource, and market economy non-existent. Gradually, however, as human population has become a more increase, forest has reduced, land has become a more expensive resource, huma has prohibited by the government, and increased market economic penetration to rural areas (cf. Kools 1935; Iskandar 1998). As a result, the swidden farming has decreased over time. Indeed, this oldest agriculture system has disappeared in many places in West Java and Banten, Indonesia. However, in some places, such as in Baduy area of South Banten, Kasepuhan area of South Sukabumi, and very refraction area of West
Java relict swidden farming has still predominantly practiced by the local people (cf. Iskandar 1998). The Baduy and Kasepuhan have annually cultivated dry-land rice in the forest area. Like the Baduy and the Kasepuhan, the local people who reside in the frontier area of Karangwangi Village, Cidaun Sub-district, Cianjur, West Java, had predominantly practiced the swidden farming in the past. Nowadays, however, they have practiced the swidden farming in the dry land (tegal or tegalan) instead of in the forest because forests which had used to practiced swidden farming, has been converted to the traditional agroforestry systems, such as the homegarden (pekarangan) and mixed-garden (kebon tatangkalan), and rice field (sawah) (cf. Soemarwoto and Soemarwoto 1984, Iskandar and Iskandar 2011). Historically, the agroforestry is a new term which was introduced by western scholars in 1970s (Von Maydel 1985), but this indigenous agricultural system has been traditionally practiced for a long time in Java (Reijntjes et al. 1992; Iskandar and Iskandar 2011). The agroforestry may be defined "as a land-use system that resembles a forest in structure and combines the natural functions of forest with those for fulfilling the socio- 
economic needs of the people" (Soemarwoto and Soemarwoto 1984). In terms of management, the agroforestry may be defined "as sustainable management system for land that increases overall production, combines agricultural crops, tree crops and forest plants and/or animal simultaneously or sequentially, and applies management practices that are compatible with cultural patterns of the local population (Raintree and Warner 2015).

On the basis of ecological or environmental history, although the shifting cultivation system had been viewed as an environmentally destructive practice in the past, recently, it has changed, many scholars suggested that some ecological and socio-economic benefits of the swidden. The some benefits of the swidden, including as adapt to changing economic and ecological condition (Colffer et al. 2015), potential sequesters of carbon (van Noordwijk et al. 2015), enhance resilience in a changing climate (Garrity 2015), benefit of biodiversity conservation (Rerkasem et al. 2009; Sajise 2015), maintaining food plants and local rice varieties (Soedjito 2015), and the useful for rehabilitation of degraded lands (Kartawinata and Abdulhadi 2015).

Historically, most swidden farming in West Java had been evolved into the traditional agroforestry types, such as mixed-garden (kebon tatangkalan) and homegarden (cf. Soemarwoto and Soemarwoto 1984; Christanty et al. 1986; Iskandar and Iskandar 2011; Kosuke et al. 2013). The evolution of agriculture from the swidden farming system to the traditional agroforestry system because this has some benefits, such as to establish more permanent land right for village farmers with those rights can be transferred to future generation, and to create more sustainable production (cf. Rahman et al. 2016).

This paper discusses the process of evolution of the swidden farming and innovation cultural practice among the Karangwangi community, South Cianjur, West Java, in management of the traditional agroforestry systems which have been dynamically affected by ecological and socioeconomic changes.

\section{MATERIALS AND METHODS}

\section{Study sites}

The present study was undertaken in the Village (desa) of Karangwangi, Sub-district (kecamatan) of Cidaun, District (kabupaten) of Sukabumi, Province (provinsi) of West Java, Indonesia. The village is located at approximately latitude $7^{\circ} 25^{\prime}-7^{\circ} 30^{\prime} \mathrm{S}$ and longitude $107^{\circ}$ $23^{\prime}-107^{\circ} 25^{\prime} \mathrm{E}$. It has the distance approximately $120 \mathrm{~km}$ from the city of Bandung and approximately $70 \mathrm{~km}$ from the town of Cianjur, with a travel time of 5-6 hours from the city of Bandung and approximately 3-4 $\mathrm{km}$ from the town of Cianjur. The Karangwangi Village is north bordering Cimaragang Village, east to Garut District, west to Cidamar Village and south by the Indonesian Ocean, and is directly bordered with the Nature Reserve (Cagar Alam) of Bojonglarang-Jayanti (Figure 1). The Karangwangi Village has a total area of about 2,300 hectares, which was inhabited by 5,587 people with 1,817 households in 2014 (Statistic of Karangwangi Village 2014). The main livelihood of the people recorded as farmer. Topographically, the Karangwangi consists of moderate to very steep slope hills, and at an altitude between 200-275 $\mathrm{m}$ above sea level (asl.). The village of Karangwangi area exhibit two main seasons: a dry season (usum halodo) and a wet season (musim hujan or musim ngijih). In general, from November to April, the south-west monsoon brings heavy rains, while from May to October the south-east monsoon brings drier weather.
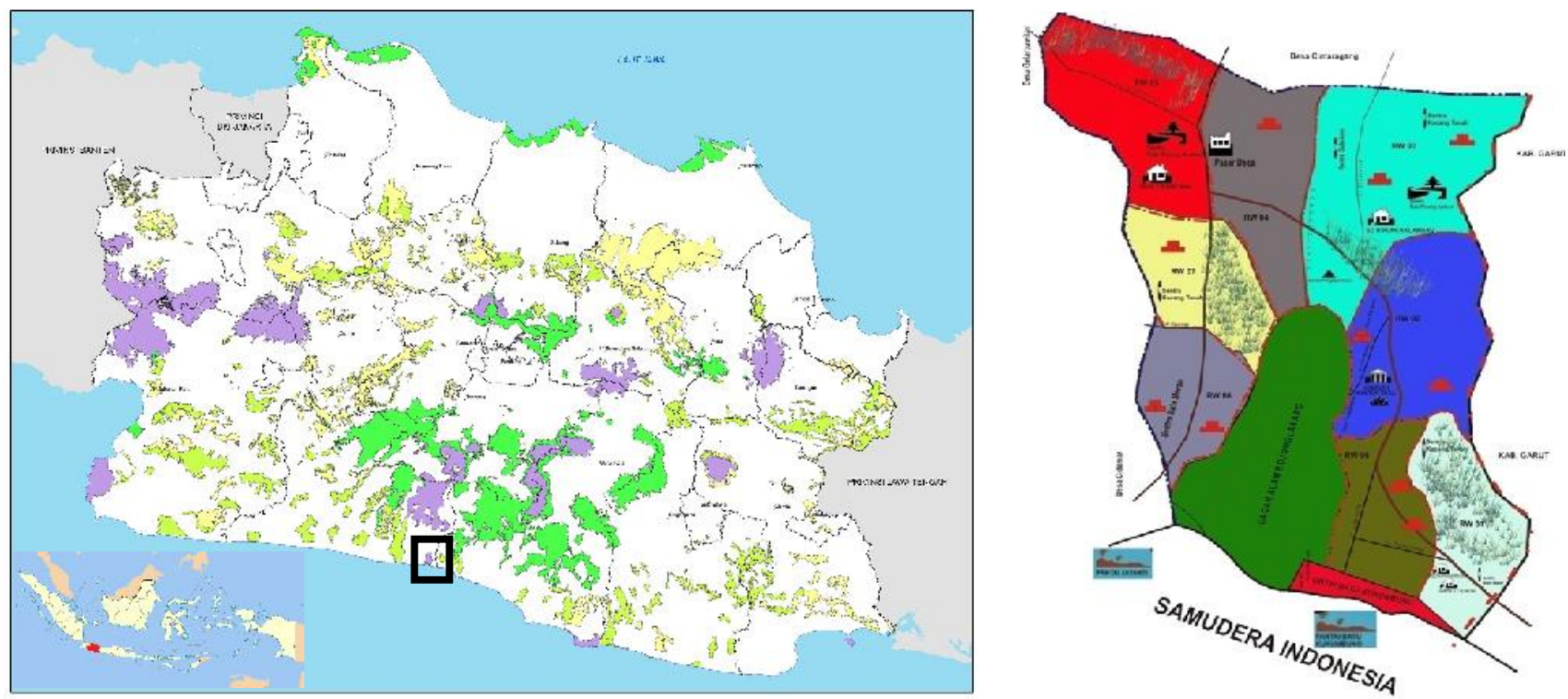

Figure 1. Research location, Karangwangi Village, South Cianjur, West Java, Indonesia 


\section{Procedure}

The method used in this study was the qualitative which is based on ethnoecological approach (cf. Martin 1995; Cotton 1996; Cunningham 2001; Newing et al. 2011; Iskandar 2012). Several techniques were applied to collect data, i.e. semi-structure interview, observation, and participant observation. The semi-structure interview was undertaken by deep interview with competent informants (local experts), which is selected by purposive considered as experts, including old farmers, informal leaders, village staffs, and village middlemen. The deep interview was based on a prepared interview guide that consists of a list of questions or topics to be covered, particularly concerning the development of the traditional agroforestry systems in the Karangwangi Village. The observation was mainly applied to observe general condition of settlement and agricultural areas, various vegetation structure of traditional agroforestry systems, and village market activities, while participant observation that was conducted by researchers accompanied one or more farmers both to observe what they do and say, and also participate, to varying degree, in the activities being studied (cf. Newing et al. 2011). For example, we actively participated in harvesting various crops in the homegarden and mixedgarden, and processing and marketing of various crop productions, particularly fruits.

\section{Data analysis}

The data analysis involved cross-checking, summarizing and synthesizing from different sources, namely obtained from semi-interviews of informants, observations, participant observations, and secondary data of village and sub-district statistical data, and used to build up a narrative account (cf. Newing et al. 2011).

\section{RESULTS AND DISCUSSION}

Owing to a lack of numerical data, nothing definite can be said about the forest acreage and growth rate of the population in the Karangwangi in early-modern West Java after the Indonesian independent. The process of ecological and socio-economic changed is predominantly elucidated instead of the quantitative analyzed in the paper. This paper is presented in four parts. In part one, we account for the Karangwangi people used to practice the swidden farming in the forest when the forest area that was still abundant. In part two, with a focus on process of the evolution of the swidden farming, transformed to the traditional agroforestry systems; and part three, discuss on the traditional agroforestry and responses to environmental changes. In part four, summarized and concluded the paper.

\section{The swidden cultivation in the forest}

On the basis of ecological history, in the ancient time the frontier areas of West Java were predominantly covered by forests with owned relatively low human population (c.f. Lombard 1996; Geertz 1963; Breeman 2014). Therefore, to adapt with the local upland environment,
Sundanese people who reside in the frontier villages, including people of Karangwangi Village, Cianjur District, West Java had developed the shifting cultivation system (huma) instead of cultivating the wet rice field cultivation (sawah). The sawah system was firstly introduced to upland areas of West Java in late of 1750 (Terra 1958; Geertz 1963).

In the past, almost all household of the Karangwangi Village and surrounding areas, including Cimaragang, and Cisewu culturally involved in practicing swidden farming in the forest. They opened the forest by moving from one places to another to practice of swidden farming. As mentioned by one of the informants that: "Baheula mah Kuring pindah kadieu (Desa Karangwangi) ti keur bujangan keneh. Kuring ngilu ka pun Bapak pikeun ngagarap huma ti daerah Cisewu, terus pindah ka daerah Cimaragang terus weh pipindahan nepi ka tuntungna pindah kadieu. Baheula ge didieu masih keneh leuweung, terus loba keneh eurih jarangkung nepika nutupan jangjalaneun". This can be translated as: “In the past, I moved to this place (Karangwangi Village) since I was bachelor. I came from Cisewu and moved to Cimaragang, and always moved, finally resided in this place. I always moved accompanied my father to practice the swidden farming (huma). At that time, in this place was predominantly covered by forest. In addition, the footpaths in the forest were covered by the tall grass of eurih (Imperata cylindrica)".

Each the village household has right to cultivate upland rice (huma) by felling mature secondary forest (reuma kolot) in different places, and planting in one or two successive years. Moreover, fallow land is not owned permanently and only perennial crops are inherited. Originally, after harvesting rice and other annual crops, fallowed land (reuma) could be cultivated by anyone, but with priority given to the previous users. Such rights disappear if rice is harvested and land returned to fallow. Therefore, each household usually moved as nomadic from one place to another to obtain fallowed land of sufficient maturity for swiddening. As a result, each household has the fallowed land between 5 to 8 plots of the fallowed land.

Culturally, to practice upland rice (huma), a piece of mature secondary forest (reuma kolot) was cleared and planted by upland rice and other annual crops, such as corn, cassava, cucumber, and various beans, strongly based on local knowledge (corpus) and cosmos or belief (cf. Toledo 2002). After harvesting rice and other annual crops, the land was fallowed and transformed into secondary forest (reuma) through natural succession. Moreover, the mature secondary forest (reuma kolot) could be opened for rice planting again in the following year or fallowed for more than 3-5 years. Each household will shift to another piece of mature secondary forest for rice planting. Thus, in ancient times, shifting cultivation was very popular in the upland of West Java, and status of huma land was considered as a tenure system. Each household of Karangwangi people usually moved from one place to other places to find appropriate mature secondary forest (reuma kolot) to practice shifting cultivation. If certain 
appropriate forest block had been found, this forest block has been given special signs (diciri or disawen), such as by tying shrubs (cf. Soepomo 1982). Thus, it means such forest block had been claimed by one family to be planted by rice and other annual crops. Moreover, forest vegetation in the signed forest block was opened in the dry season, and various vegetation biomasses were dried and burned, and then the land is readily planted by rice. In the beginning of the wet season, the land was planted by various local upland rice varieties, such as pare sintung, or popularly called as pare buhun or pare jampang and other annual crops, such as beans, including kacang hiris (Cajanus cajan). The forest land was planted by upland rice varieties and other annual crops are called huma (cf. Iskandar and Ellen 1999; Iskandar and Iskandar 2011). After planting rice approximately 5 month, the rice paddy was harvested and other annual crops was sequentially harvested between 1 and 6 months after harvesting rice depend on kind of crops. The huma land was recultivated in next year or fallowed between 3 and 5 years. The fallowed huma land less than one year that was still predominantly by straw (jarami) is called jami. The following year, the jami was replanted by upland rice or fallowed (dipreikan or diperdiokeun) that will developed to be form of the immature secondary forest (reuma ngora) with fallowed time 2-3 years, and mature secondary forest (reuma kolot) of fallowed time more than 3 years by natural succession. Before the fallowed secondary forests were readily recultivated the cultivator would move from one block to other forest block to practice the shifting cultivation (huma). Generally, the cultivators would be come back to recultivated the former fallowed secondary forest, after fallowing time more than between 3 and 5 years. Based on the farmer perception, the soil fertility of the fallowed mature secondary (reuma kolot) of fallowing time more than 3-5 years considered has been recovery. It is caused the top soil has been provided by some amount of litters over time during fallowed time and became compost (cf. Sanchez 1976; Okigbo 1984). Therefore, the secondary mature forest can be reopened to be replanted by upland rice and other annual crops. Culturally, the fallowed mature secondary forests might be recultivated by the former owners who the first opened the forest or may be cultivated by other farmers but they must get special permission from the former huma owners. Therefore, basically, the swidden system practiced by village people of Karangwangi had cycle, namely "the mature secondary forest (reuma kolot) swidden field (huma) - immature secondary forest (reuma ngora) - mature secondary forest (reuma kolot) - swidden field (huma)" continuously over time.

During the cultivating rice (ngahuma) in the forest block, each household culturally built a farm house (saung huma) in his swidden field (huma). Some farmers between 3 and 5 usually built farm houses in located very closely one and each other's in a group. These farm houses would establish more permanent swidden and farm house grouping that is called catihan. Moreover, if one or two new farm permanent houses were built in the catihan and would develop to be umbulan (one or two permanent houses in a farm). Eventually, the umbulan would develop to be babakan (new hamlet consisting of houses). Ampian or kampung (hamlet consisting of 10-50 houses), and desa (consisting of some hamlets or administrative village) (cf. Iskandar 1998). At the present time many people who reside in the Karangwangi had originally came from neighboring villages, such as Cimaragang, Cianjur District and Cisewu, Garut District who predominantly used to swiddeners (peladang or pahuma) in the forest.

\section{The evolution of the swidden farming}

According to some informants, until the late of the twenties century, some people of Karangwangi Village had predominantly practiced the shifting cultivation or swidden cultivation in the forest due to still abundant forest area. In the past, the cultivation of dry rice was yearly undertaken by village farmers in once, only during the wet season. Various methods particularly environmental indicators were used by village farmers to start the swidden farming. For example, the appearance of position of bintang kidang (the belt of Orion) was usually used as indicators to determine the swidden farming activities. Culturally, the planting the upland rice of the swidden farming was begun when the kidang appears overhead (nyuhun). Another environmental indicator, the flowering and fruiting of the beurih (Aporosa frutescens; Family of Euphorbiacea), that the flowering of which usually synchronize with the beginning dry season. Conversely, the ripening and falling down of the fruits which usually synchronize with the beginning wet season. In addition to annual cycle of precipitation and various within it, Karangwangi also recognized a cycle of eight named years, which is called windu. The windu consists of alip, he, jim awal, je, dal, be wau, and jim akhir (cf. Iskandar 2007). Each named year in the cycle is said to exemplify special characteristic in relation to climate and the panting of appropriate crops which is mentioned by informants as follow (Table 1):

However, by the 1970s, the practice of swidden farming had been dramatically reduced due to various factors, such as increasing of human population, decreasing forest areas, and increasing market economic penetration to villages. Based on interview with the informants, the human population in the Karangwangi was still very low. They resided in the scatter hamlets which were closed to the swidden field. Administratively, the Karangwangi Village was established in 1984 and developed from the previous village, Cidaun Village. Since the early 1970s, the natural mature forest of the Karangwangi have disappeared due to converted to swidden field and fallowed lands. Indeed, the relic mature forest with total of 750 ha, was decreed by the national government as the nature conservation called Bojonglarang-Jayanti Nature Reserve. Nowadays, the total area of the Karangwangi was recorded 2,300.17 ha. The land use types can be divided into categorized, namely swidden (huma) 450 hectares, homegarden 1.8 hectares, mixed-garden 5 hectares, dry land (tegalan) 47 hectares, village people plantation (perkebunan rakyat) 5 hectares, semi-technical irrigation rice field (irigasi setengah teknis) 45 hectares, simple irrigation rice field (irigasi sederhana) 150 hectares, rain fed rice field (sawah tadah hujan) 760 hectares, and tidal rice field (sawah pasang surut) 12 
Table 1. Names of year in a cycle of eight years (windu)

\begin{tabular}{|c|c|c|}
\hline Name of year & Special characteristic & Which can be translated as \\
\hline 1. Alip & Halodo panjang, tapi pepelakan bakal sae & The long dry season, but crops might be growing \\
\hline 2. $\mathrm{He}$ & Halodo henteu pati panjang, pepelakan kirang sae & $\begin{array}{l}\text { The dry season is not too long, crops might be growing } \\
\text { not so well }\end{array}$ \\
\hline Jim awal & Hujan seueur, pepelakan sae dina akhir taun & $\begin{array}{l}\text { A lot of rain in the wet season, crops might be growing } \\
\text { well at the end of year }\end{array}$ \\
\hline Dal & $\begin{array}{l}\text { Kirang hujan, pepelakan paparengan kadang- } \\
\text { kadang sae atawa won }\end{array}$ & $\begin{array}{l}\text { Lack of the rining, crops sometimes might be growing } \\
\text { well or might be not so well }\end{array}$ \\
\hline$B e$ & Seueur hujan, sae kanggo pepelakan & A lot of raining and good for growing crops \\
\hline Wau & Halodo pamjang tapi pepelakan sae & The long dry seson and crops might be growing well \\
\hline
\end{tabular}

hectares. In term of population, the total population of the Karangwangi was recorded 5,587 people and 5,672 people, in 2013 and 2014, respectively. The total population has dynamically changed by birth rate, death rate, and outmigration rate. The out-migration rate has been recorded rather high due to a lot of people migrated to Middle East as female $(\mathrm{TKW}=$ Tenaga Kerja Wanita; Indonesian women labor) and the male laborers. For example, 181 people consist of 14 males and 167 females were recorded in 2014 as the laborers (TKI = Tenaga Kerja Indonesia; Indonesian labor) in the Middle East countries (Karangwangi Village 2014).

By increasing human population, therefore, some fallowed secondary forests have been converted to dry land (tegalan) and usually cultivated by upland rice (huma) system and annual non-rice crops (kebon) system during the wet season. In addition, some areas of the tegalan have been cultivated into wet rice fields (sawah) system. Moreover, the wet rice fields system may be divided into some categories, namely irrigated rice fields (sawah irigasi) system and non-irrigated rice fields (sawah non irigasi) or rain fed system. Besides, some fallowed secondary forests and uplands (tegalan) have also been converted into the more permanent mixed-garden, planted by mixture of annual and perennial crops, which is locally called as kebon bambu (if bamboo trees are predominantly planted in garden), kebon albasiah (if albizia trees are dominant) or kebon tatangkalan (if various trees are dominant). It is also recognized with some local names in different places, such as talun in Soreang, South Bandung (Christanty et al. 1986; Mizuno et al. 2013), kebon tatangkalan in upper Citarum Watershed (Parikesit et al. 2004), dudukuhan in villages of Bogor (Manurung et al. 2005), or dukuh lembur in Baduy, South Banten (Iskandar 1998). This traditional agroforestry system is culturally predominantly planted by perennial crops, such as fruits and building materials. Sometimes, the kebon tatangkalan may be converted to huma (mainly panted by upland rice) and kebon (mainly planted by annual non-rice) during the wet season. Eventually, various land use types, dry land (tegalan), reuma, kebon and kebon tatangkalan, and sawah have been converted into settlement and homegarden, if in those land use types are constructed houses (Figure 2).

The huma, kebon tatangkalan, and pekarangan have predominantly planted by mixed of annual and perennial crops. Moreover, these traditional agroforestry systems have been culturally planted not only by rich species but also by local plant varieties (landraces). Since the huma, kebon tatangkalan, and pekarangan cultivated by various annual and perennial crops, the structure vegetation of these agricultural types similar to that of natural forest and we classified as the traditional agroforestry system. In this case, it means the land use type system that resembles a forest in structure and combines the natural or ecological functions of forest those for fulfilling the socio-economic and cultural needs of the people (cf. Soemarwoto and Soemarwoto 1984). The natural/ecological functions consist of hydrologic and erosion control, gene bank, microclimatic effects, enhance resilience enhance in changing climate, and potential carbon storage for reducing Emissions from the Deforestation and Forest Degradation (REDD), and animal habitats, particularly birds, insect and small mammals (cf. Soemarwoto and Soemarwoto 1984; Garrity 2015; van Noordwijk et al. 2015).Meanwhile, its socio-economic and cultural functions, include subsistence and commercial production, and socio-cultural functions. Subsistence productions of the traditional agroforestry system consists of additional staple food (taro, cassava, corn, etc.), vegetables, fruits, traditional medicines for curing of human and livestock health, and firewood and material buildings, whereas its commercial production, including fruits (orange, mango, sawo, banana, etc), and industrial materials (albizia woods, coconut, sugar palm, bamboos, etc.) (cf. Christanty et al. 1986; Jensen 1995; Okubo et al. 2010; Kosuke et al. 2013; Abdoellah et al. 2015). In addition, some crop production can fulfill various cultural functions, including aesthetical value, and the traditional ceremonies. 


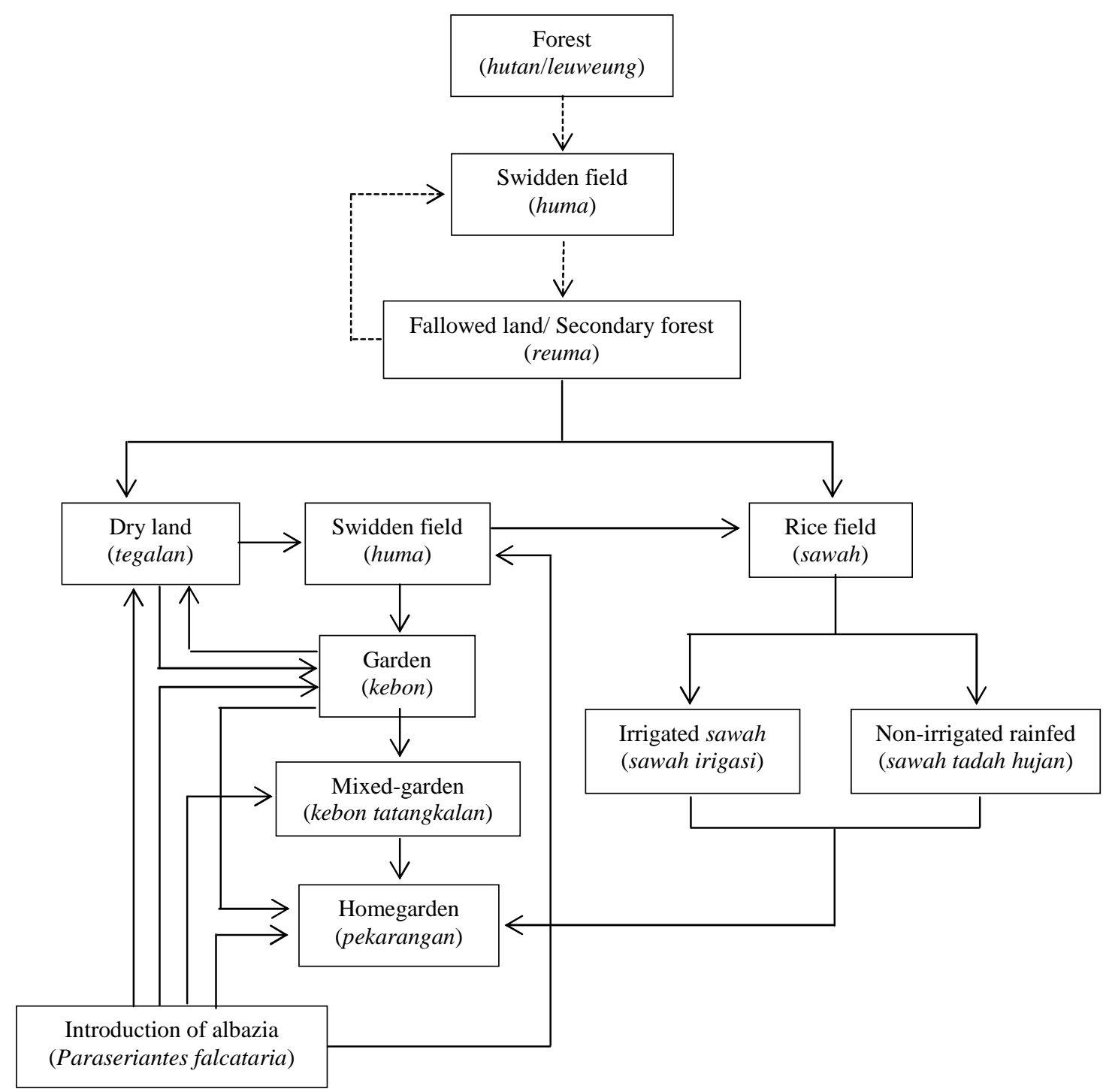

Figure 2. Evolution of the traditional agroforestry system derived from forest, and introduction of albizia (Paraserianthes falcataria) in the village of Karangwangi, Cianjur, West Java

Unlike in the past, nowadays the Karangwangi have practiced the swidden farming in the dry land (tegalan) instead of the forest area because the forests were converted to the traditional agroforestry, namely homegarden and mixed-garden and relict forest was converted to the Nature Reserve of Bojonglarang-Jayanti. The swidden farming system has been modified and adapted to local ecological and socio-economic condition. For example, the upland rice farming was normally cultivated by modern rice varieties mixed with corn varieties and beans. In addition, some inputs, such as seeds, pesticides, and industrial chemical fertilizers have been introduced from the market or urban area.

\section{The traditional agroforestry systems and responses to environmental and economic changes}

The last several decades, the traditional agroforestry systems of Karangwangi Village have been affected by various environmental and socio-economic changes. For example, a village road existed from Karangwangi to Cianjur by the Dutch to service plantation in the area. However, access to Karangwangi from the district of Cianjur was constructed by the early 2000s predominantly made of river stones. However, since 2009 the village road of Karangwangi has been upgraded by using asphalt. In addition, several bridges over the village road, including Cikawung and Cilaki Rivers have been built by permanent constructions. As a result, some vehicles now comfortably travel between the Karangwangi Village and Cianjur, Garut or Bandung urban. Since more easily access between Karangwangi and urban areas of Cianjur, Garut, and Bandung, the market economic system has intensively penetrated. For example, in the past the various agricultural productions of the agricultural productions, including the traditional agroforestry had been culturally traded in the village market. It has been recorded one village market in 
Karangwangi, namely Pasar Desa Puncak Bayuning which is regularly operated weekly in Monday. In addition, some other village markets are also found in the Karangwangi adjacent areas, including Pasar Palabuhan Jayanti of Cidamar Village which is regularly weekly operated in each Sunday, Pasar Naringgul of Naringgul Village weekly operated in Sunday, Pasar Mangunjaya of Mangunjaya Village in Monday, Pasar Kertajati of Kertajati Village in Thursday and Thursday, and Pasar Ciujung of Mangunjaya Village in Friday. Nowadays, however, the number of small shops (warung) and permanent shops (toko) in the Karangwangi has increased. For instance, 97, 103, and 200 small shops and permanent shops were recorded in 2012, 2013 and 2014, respectively (Cidaun Sub-district 2015).

By rapid developing the transportation and communication, consequently, the agricultural land has increasingly demanded by urban people to establish commercial gardens or plantations, such as oil palm plantation. Indeed, the agricultural land price has dramatically increased. At the same time, some traditional agroforestry systems have also been predominantly converted to more commercial monoculture system, such as homogenization of Moluccan albizia (Paraserianthes falcataria).

Despite socio-economic and environmental events, including recent irregularly drought and the $2015 \mathrm{El} \mathrm{Nino,}$ the Karangwangi traditional agroforestry systems, including the huma system have been maintained and overall production levels have not been seriously affected compared to intensive wet rice field (sawah) farming in the lowland northern parts of West Java. It is caused of the Karangwangi people have developed some appropriate strategies, including development of the adoption of land certification, planting crop diversification; introduction of albizia; involving in petty trading; and diversification of off-farm job activities (cf. Iskandar 2007).

\section{Land certification}

As mentioned earlier that in the past, the Karangwangi culturally practiced the swidden in the forest which each household owned the swidden field and other swidden fallowed fields at the form of the secondary forest (reuma) in different fallowed times with have status as the tenure system. Today, however, most people of the Karangwangi people annually predominantly practice shifting cultivation (ngahuma) in non-forest areas, particularly by cultivating the upland field (tegal) and mixed-garden. Moreover, the dry fields (tegal) can be divided into two categories, namely the certified land (tanah sertifikat) and noncertified land (tanah pangangonan or grazing land). Recently, the dry lands have been predominantly certificated. For example, 2,780 plots which have total 360 hectares consist of 230 plots of 45 hectares and 2,550 plots of 315 hectares have been certified via the National Program and Redistribution, respectively. Meanwhile, the rest of the uplands have not been certified 500 plots of 350 hectares (Karangwangi Village 2014). The land certifications have tended to increase due to increasing of village human population parallel with the increase of food demand and development of agricultural technology, and increasing both land use intensity and labor intensity (cf. Boserup 1965; Raintree and Warner 2015). In other words, the people of Karangwangi have engaged in obtaining the land certification may be considered as strategy of people to get more secure on the land ownership system and to avoid social conflict on the land ownership in the near future. At this time, by improving the village road and more easily assess from the city, the land price has dramatically increased and many people of urban would like to buy the land for various purposes, including establishing the commercial plantations, such as oil palm plantation. Based on our study, we can predict that a lot of the agricultural land may be sold to outsiders and some social conflict on agricultural land conflict in the village may be occurred in the near future. Particularly, if the village leader and other stake holders have not consistently to maintain village lands that are bought by outsiders.

\section{Planting crop diversification}

Culturally, various traditional agroforestry types in Karangwangi, including the homegarden, mixed-garden, and swidden farming (huma) have been planted by a high diversity of plants. For example, based on survey 81 homegardens of Karangwangi Village, it was recorded 141 species of 61 families, with 62 per cent categorized as food materials (Aniya 2015). In addition, at least it was recorded 13 species of bamboo and 13 varieties (landraces) of banana (Musa sp.) in the traditional agroforestry of mixedgarden. Because the high species and varieties of local plant planted in various traditional agroforestry system; as a result it has been an important role as genetic sources which can be used for plant breeders to create new crop varieties in supporting the sustainable agricultural development to anticipate against future risk and uncertainty, caused of environmental stresses, including drought, flooding, and outbreak pests.

In addition, the biodiversity of plants of the traditional agroforestry systems have been an important to enhance the mitigation and adaptation of farmers and environmental and market economic changes. Generally, the high plant diversity planted in the traditional agroforestry systems has strongly related to stability of this traditional agroforestry on pest outbreak, drought, flooding, and economic changes (cf. Iskandar 1998; Iskandar 2007). For example, recent irregularly drought and the 2015 El Nino serious affected on rice production of the lowland rice field (sawah) farming of West Java. However, unlike the lowland sawah farming, the production of several types of the traditional agroforestry systems of Karangwangi, including homegarden and mixed-garden have severely reduced cased of drought. Empirically, during the dry season and drought time, the number of annual crops has decreased; but some perennial crop productions, such as bamboos, building material woods, such as albizia and jabon and various fruits, including sawo (Manilkara zapota), mangga (Mangifera indica), and alpuket (Persea americana) have not been not seriously damaged by drought. Conversely, by dry season and drought with full sun and full, might maximal produce fruits in the home gardens and mixedgardens (cf. Iskandar 2007). 


\section{Introduction of albizia}

Initially, Moluccan albizia or locally known as albasiah or sengon (Paraserianthes falcataria) and jabon (Anthocephalus sp.) were introduced in Karangwangi Village by the Forestry Office (Dinas Kehutanan) through the regreening program to rehabilitate the degradation forest and the former secondary fallowed land of the swidden system in 2000s. More recently, many people have popularly adopted these trees, particularly albizia trees planted in their upland fields (tegalan), swidden fields (huma) or mixed-gardens (kebon tatangkalan). Generally, the albizia trees have been predominantly planted in tegalan with monoculture system; whereas in the huma and kebon tatangkalan have been commonly planted with polyculture system (tumpang sari) which is strongly embedded by 'hybrid knowledge' (cf. Iskandar and Ellen 2000). Culturally, the albizia trees have been planted mixed with annual and perennial crops, such as upland rice (Oryza sativa), kacang hiris (Cajanus cajan), kacang tanah (Arachys hipogaea), cau (Musa paradisiaca), kapolaga (Elettaria cardamomum), and mahoni (Swietenia mahagoni). In the past, seeds of albizia were freely provided by the Forestry Office of Cianjur District (Dinas Kehutanan). Today, however, seeds of albizia are obtained from different sources, such as prepared by farmer themselves to make seedbed in the polybags, buy from other people at the same village who usually sell seeds by paying cash or credit, and buy from small shops in Subdistrict of Cidaun and Rancabuaya. If the albizia trees are planted by intercropping with annual crops, they are commonly provided by various fertilizers, such Urea, NPK, Poskaan, and animal dung at least one time.

About between 5 and 7 years after planting, the albizia trees have been readily to harvest. The albizia wood production can be used for various household purposes and for commercial purposes. There are three model of harvesting albizia trees, particularly if the trees are going to sell. Firstly, all trees are totally sold by the owners to middlemen, and by paying cash before harvesting time, called as 'selling wholesale' (jual borongan). Secondly, the albizia trees are sold to buyers in cubic meter, selling the albizia trees that have been cut and special length measure between $130 \mathrm{~cm}$ and $160 \mathrm{~cm}$, called as jual cara palet. It has price between $\mathrm{Rp} 670,000$ and $\mathrm{Rp} 890,000$ per $\mathrm{m}^{3}$.Thirdly, the albizia trees are sold in the form of that has been processed in to the form of wood beams (balok) and planks (papan), which can be used for various purposes, such aschair furniture (mebel). It has price between $\mathrm{Rp}$ $1,500,000 / \mathrm{m}^{3}$ and $\mathrm{Rp} 2,000,000 / \mathrm{m}^{3}$.

\section{Involving in petty trading}

Productions of various traditional agroforestry systems, including huma, pekarangan, and kebon tatangkalan of the Karangwangi have been used both to fulfill household daily needs and some surpluses usually to sell to middle men and consumers in the weekly village markets. For example, various traditional agroforestry products, including gula aren (sugar palm, Arenga pinnata), cau, sawo, mangga, alpuket, petai (Parkia speciosa), and jengkol (Archidendron pauciflorum) are commonly sold in the weekly village markets, such as Pasar Desa Puncak Bayuning of Karangwangi Village and Pasar Palabuhan Jayanti of Cidamar village.

Today, in response to more intensive market economic penetration, many people in Karangwangi have been involving in petty trading as middlemen by trading various the traditional agroforestry products sold in the weekly markets (pasar mingguan desa) and village small shops (warung). In addition, some people have been involving in selling albizia seeds, albizia woods, bamboos, and fermented banana (sele pisang).

\section{Diversification of off-farm jobs}

Increasing people adoption of cultivating albizia in various traditional agroforestry systems have provided some benefits for local people, including in provide the offfarm job opportunity. For example, many people have involved in some jobs of harvesting albizia trees. Generally, albizia trees are cut by assisting some laborers, namely as woodcutter with chainsaw (tukang nyenso), carrying albizia logs, and transporting albizia logs. In addition, home industry in relation to process albizia woods for various products, such as table, chair, and cupboard. As a result, some people have involved as carpenters and construction workers.

Utilization of bamboos and bananas which are produced from the agroforestry systems has also provided some offfarm jobs for the local people. Generally, bamboo trees are commonly used to fulfill various people needs and to sell to middlemen. In addition, some people have engaged in the off-farm jobs in relation to bamboo production processes, including making various household utensil and handicrafts made of bamboo materials, such as bamboo wall (bilik awi), bamboo chair (kursi bambu), bamboo winnowing (nyiru), and bamboo basket (cerangka). Like bamboo, banana productions have generally used for fulfill households as food for home consumption. Some banana products, however, have also been industrially processed by households making the fermented banana (pisang sale). Moreover, the fermented bananas have been sold in villages and sent to urban markets of Cianjur and Bandung.

This paper has discussed on ecological or environmental historical of the shifting cultivation in West Java, particularly based on case study carried out in Karangwangi Village (cf. Boomgaard 1997). We begin describe the shifting cultivation system (huma) that was undertaken by the local people in the past. At that time, the local people farmed various local upland rice varieties and other annual crops in the forests which are strongly embedded by traditional local knowledge and cosmos (cf. Iskandar 1998; Toledo 2000; Iskandar 2007). The farming of huma practiced in the past may be considered as cultural adaptation and achieved extremely efficient and sustainable agricultural system of the frontier upland of West Java, when forest was still large, land was cheap resource, human population was low, labor was the expensive resource and economic market non existent. Gradually, however, as forest reduced, population increased, land has become a more expensive resource and market economy has intensively penetrated to rural areas, swidden 
agriculture has become less advantageous economically and less sustainable ecologically (cf. Bunch 2015). As a result, the traditional shifting cultivation system of the Karangwangi had developed into other traditional agroforestry systems, such as homegarden and mixedgarden and land tenure system have gradually changed to fixed ownership system by obtaining land certificate. In parallel with intensive market economic penetration to rural areas, commercial trees, namely albizia have been culturally adopted by the local people. This species has been culturally adopted due to provide some ecological and economic benefits. For example, the albizia is categorized as Leguminoceae family, capable improving soil fertility through nitrogen fixation, easily cultivated, provides for various needs, as well as yielding cash income (cf. Iskandar and Ellen 2000). Moreover, to adapt with ecological and socio-economic changes, such as forest and agricultural decrease, human population increase, and intensive market economic penetration increase, the Karangwangi people have developed some appropriate strategies, namely maintaining various traditional agroforestry systems and also various factor that can maintain their traditional agroforestry and their income, including adoption of land certification, planting crop diversification; involving in petty trading; and diversification of off-farm job activities.

In conclusion, by developing innovation cultural practice, Karangwangi people of South Cianjur, West Java have tended to success to evolve their shifting cultivation to new condition of the traditional agroforestry systems in sustainable way, despite population growth, the depletion of the forests, and intensive market economic penetration.

\section{ACKNOWLEDGEMENTS}

This study is one of the topics of the program of Academic Leadership Grant of Prof. Johan Iskandar, funded by DIPA Padjadjaran University, Indonesia fiscal year 2015. Therefore, on this occasion we would like to thank Prof. Dr. med. Tri Hanggono Achmad, rector of Padjadjaran University, who has provided Academic Leadership Grant as implementation to achieve Word Class University. In addition, we also would like to thank the field assistants of the team Anthropology and of Biology Padjadjaran University, namely Riki, who have assisted collect field data. In this opportunity, we also conveyed gratitude to the village head of Karangwangi Village and his staff, along with the informants of Karangwangi who have kindly helped us to provide information.

\section{REFERENCES}

Abdoellah OS, Pariksit, Okubo S, Withaningsih S, Takeuchi K, Mizuno K. 2015. Perception of owners on the Roles and Future of Bamboo-Tree Gardens in the Agricultural Landscape of the Upper Citarum Basin, West Java-Indonesia. Agri Sci 6: 1333-1351

Aniya MU. 2015. Plant diversity studies and functions utilization courtyard in the Village Karangwangi Cidaun Sub-district of Cianjur District, West Java. [Research Report]. Padjadjaran University, Bandung [Indonesia].

Boomgaard P. 1997. Introducing environmental histories of Indonesia. In Boomgaard, Colombijn F, Henley D (eds) Paper Landscapes: Explorations in the environmental history of Indonesia. KITLV Press, Leiden.
Boserup E. 1965. The conditions of agricultural growth: the economics of agrarian change under population pressure. George Allen \& Unwin Ltd., London

Breman J. 2014. Colonial Advantage of the Forced Labor System of the Plant Forced Priangan coffee in Java. Yayasan Pustaka Obor Indonesia, Jakarta. [Indonesia]

Bunch R. 2015. Learning from migratory agriculture around the world. In: Cairns MF (eds). Shifting Cultivation and Environmental Change: Indigenous People, Agriculture and Forest Conservation. Routhledge, London.

Bunch, R. 2015. Learning from migratory agriculture around the world. In: Cairns MF (eds). Shifting Cultivation and Environmental Change: Indigenous People, Agriculture and Forest Conservation. Routhledge, London.

Christanty L, Iskandar J, Abdoellah OS, Marten GG. 1986. Traditional agroforestry in West Java: The pekarangan (homegarden) and talun-kebun (annual-perennial rotation) cropping systems. In: Marten GG (eds). Traditional Agriculture in South East Asia: A Human Ecology Perspective. Westview Press, Boulder.

Cidaun Sub-district. 2015. Statistical data of Cidaun Sub-district 2015. Cidaun, Cianjur.

Colfer CJP, AlcornJB, Russell D. 2015. Swidden and fallows: Reflections on the global and local values of 'slash and burn'. In: Cairns MF (eds). Shifting Cultivation and Environmental Change: Indigenous People, Agriculture and Forest Conservation. Routhledge, London.

Cotton CM. 1996. Ethnobotany: Principles and applications. John Willey and Sons Ltd, London.

Cunningham AB. 2001. Applied Ethnobotany: People, World Plant Use and Conservation. Earthscan Publication, London.

Garrity D. 2015. Learning to cope with rapid change: Evergreen agriculture with rapid change: Evergreen agriculture transformations and insights between Africa and Asia. In: Cairns MF (eds). Shifting Cultivation and Environmental Change: Indigenous People, Agriculture and Forest Conservation. Routhledge, London.

Geertz C. 1963. Agricultural involution: The Processes of ecological change in Indonesia. University of California Press, Berkeley.

Iskandar J, Ellen FR. 1999. In Situ Conservation of rice landraces among the Baduy of West Java. J Ethnobiol 19 (1): 97-125.

Iskandar J, Ellen FR. 2000. The Contribution of Paraserianthes (Albizia) falcataria to sustainable swidden management practices among The Baduy of West Java. Human Ecol 28 (1): 1-17.

Iskandar J, Iskandar BS. 2011. Sundanese People Agroecosystem. Kiblat Utama Press, Bandung. [Indonesia]

Iskandar J. 1998. Swidden cultivation as a form of cultural identity: The Baduc case. [Dissertation]. University of Kent at Canterbury. UK

Iskandar J. 2007. Responses to environmental stress in the Baduy Swidden system, SouthBanten. In Ellen RF. (eds). Modern Crises and Traditional Strategies: Local Ecological Knowledge in Island Southeast Asia. Berghan Books, New York.

Iskandar J. 2012. Ethnobiological and Sustainable Development. [Research Report]. University of Padjadjaran, Sumedang. [Indonesian]

Jensen M. 1995. Woodfuel Productivity Systems in Asia: A Review of Current Knowledge. FAO, the United Nations, Bangkok.

Karangwangi Village 2014. Statistical Data of Karangwangi Village 2014. Karangwangi Village, Cianjur.

Kartawinata K, Abdulhadi R. 2015. Fallows and forest restoration. In: Cairns MF (eds). Shifting Cultivation and Environmental Change: Indigenous People, Agriculture and Forest Conservation. Routhledge, London.

Kools JF. 1935. Hoemas, Hoemablokken en Boschreserves in de residentie Bantam. H. Veenman \& Zonen, Wageningen.

Kosuke M, Mugniesyah SS, Herianto SSet al. 2013. Talun-huma, Swidden Agriculture, and Rural Economy in West Java, Indonesia. Southeast Asia Stud Kyoto Univ 2 (2): 351-381

Lombard, D. 1996. Nusa Jawa: Cross-cultural Study of Integrated History. Gramedia Pustaka, Jakarta. [Indonesia]

Manurung GES, Roshetko JM, Boedihasono S et al. 2005. Dudukuhan: traditional farming systems for poverty reduction. In Ploeg V, Masipiquena VD (eds). The Future of the Sierra Madre: Responding to Social and Ecological Changes. Proceeding of the $5^{\text {th }}$ International Conference on Environmental and Development. CVPED, Golden Press, Tuguegararo.

Martin GJ. 1995. Ethnobotany: A Methods Manual. Chapman \& Hall, London.

Newing H. 2011. Conducting Research in Conservation: A Social Science Perspective. Routledge, London.

Okigbo BN 1984. Improve permanent systems as an alternative to shifting cultivation intermittence cultivation. In: Okigbo BN (eds). Improved Production Systems as an Alternative to Shifting Cultivation. FAO, Rome.

Okubo S, Parikesit, Harashina K et al. 2010. Traditional perennial crop-based groforestry in West Java: the tradeoff between on-farm biodiversity and income. Agrofor Syst 80: 17-31.

Parikesit, Takeuchi T, Tsunekawa A et al. 2004. Kebon tatangkalan: a disappearing agroforest in the Upper Citarum Wtershed, West Java, Indonesia. Agrofor Syst 63: 171-182.

Rahman SA, Jacobsen JB, Healey JR. 2016. Finding alternatives to swidden agriculture: does agroforestry improve livelihood options and reduce pressure on existing forest? Agroforest Syst. DOI 10.1007/s10457-016-9912-4

Raintree J. Warner K. 2015. Agroforestry pathways revisited: voices from the past. In: Cairns MF (eds). Shifting Cultivation and Environmental Change: Indigenous People, Agriculture and Forest Conservation. Routhledge, London.

Reijntjes C, Haverkort B, Waters-Bayer B. 1992. Farming for the future: An introduction to low-external-input and sustainable agriculture. The MacMillan Press Ltd, London. 
Rerkasem K, Lawrence D, Padoch C et al. 2009. Consequences of swidden transition for crop and fallow biodiversity in Southeast Asia. Human Ecol 37: 347-360.

Sajise PE. 2015. Biodiversity and swidden agroecosystems: An analysis and some implications. In: Cairns MF (eds). Shifting Cultivation and Environmental Change: Indigenous People, Agriculture and Forest Conservation. Routhledge, London.

Sanchez PA. 1976. Properties and Management of Soil in the Tropics. Willey Interscience, NewYork.

Soedjito H. 2015. Shifting cultivators, curators of forests and conservators of biodiversity: The Dayak of East Kalimantan, Indonesia. In: Cairns MF (eds). Shifting Cultivation and Environmental Change: Indigenous People, Agriculture and Forest Conservation. Routhledge, London.

Soemarwoto O, Soemarwoto I. 1984. The Javanese rural ecosystem. In Rambo AT, Sajise PE (eds). An Introduction to Human Ecology Research on Agricultura Systems in Southeast Asia. East-West Environment and Policy Institute, Hawaii.
Soepomo. 1982. Customary Civil Law in West Java. Penerbit Djambatan Jakarta. Indonesian]

Terra GJA. 1953. The Distribution of mixed-gardening on Java. Landbouw 25: 163 223.

Terra GJA. 1958. Farm system in South-East Asia. Netherland J Agri Sci 6 (3): $1157-1182$.

Toledo, V.M. 2002. Ethnoecology: A Conceptual Framework for the Study of Indigenous Knowledge of Nature. In J.R. Stepp, F.S. Wyndham, and R.K. Zarger (eds). Ethnobiology and Biocultural. The International Society of Ethnobiology, Georgia.

Van Noordwijk M, Minang PA, Hiriah K. 2015. Swidden Transitions: In an era of climate-change debate. In: Cairns $M$ (eds). Shifting Cultivation and Environmental Change. Earthscan, New York, USA

Von Maydell, 1985.The contribution of agroforestry to World Forestry Development. Agrofor Syst 3: 83-90. 